\title{
OPEN PRICING AGREEMENTS AND THE DISSEMINATION OF DATA UNDER THE COMBINES INVESTIGATION ACT
}

\author{
R.S. NOZICK*
}

\begin{abstract}
Attempts to enforce the prohibition against price fixing in the Combines Investigation Act have resulted in confusion regarding the distinction between actual price fixing agreements, open pricing agreements and data dissemination agreements. This confusion arises due to the similarity in the motivation for entering into the three types of agreements and in the consequences of the agreements. The author considers the legality and the ramifications for competition policy of agreements facilitative of open pricing. Most open pricing agreements are probably illegal under the Combines Investigation Act, Mr. Nozick concludes, and almost all such agree. ments are harmful and should be prohibited. Data dissemination agreements, while probably not illegal, have anti-competitive effects, and accordingly should be regulated.
\end{abstract}

\section{INTRODUCTION}

Firms accused of price fixing sometimes respond with the defence that they have merely engaged in "open pricing". But what precisely is meant by "open pricing"? There is considerable confusion about the exact meaning of the phrase. In this paper it is my objective to: -

1) assess the legality under the Combines Investigation Act (hereafter referred to as "C.I.A." of agreements facilitative of "open pricing",

2) explore the ramifications for competition policy of such agreements, and

3 ) in the light of current government proposals to amend the CIA, to suggest changes in this area of Canadian anti-trust law which in my opinion is not satisfactory.

There are three practices sometimes characterized as "open pricing" which should be distinguished. The first is the practice of individual firms, arrived at without the aid of any agreement, of publicizing price lists and/or other pricing data and of adhering to such publicized prices when quoting or tendering on individual contracts. While this practice may be referred to as "open pricing",2 it is not an agreement. Because of absence of any agreement the practice will fall outside the scope of $s .32$ of the CIA.

The second practice is that of competitors agreeing to announce prices publicly and to adhere to such publicly announced prices in actual transactions. I refer to such agreements as "open pricing agreements" (OPA s).

Yet a third practice relates to agreements by which competitors agree to disseminate pricing and perhaps other data, but they do not

* Professor of Law, Faculty of Law, University of Alberta. Edmonton.

1. R.S.C. 1970 , c. C-23, as amended,

2. The Restrictive Trade Practices Commission (hereinafter referred to as "RTPC") makes the distinction between "open prices" and an "Open Price Policy", the former being mere publication of price lists, the latter including an agreement to adhere to published prices. See RTPC Report in the Matter of an Inquiry Relating to the Production, Manufacture, Sale and Supply of Corrugated Metal Pipe and Related Products. No. 52 , at 54 . 
necessarily agree to adhere to public or list prices. Because the subject matter of such agreements need only be the exchange of information, they are best referred to as "data dissemination agreements" (DDA s).

The independent practice of publicizing list prices may, depending on the circumstances, have potential anti-competitive effects. However, such conduct is not illegal and it would be difficult, as a practical matter, to prohibit or even regulate it. Accordingly, it falls outside the scope of this paper.

The second and third practices should be distinguished from actual price fixing agreements. In a price fixing agreement parties agree to set a price or a price range to be quoted by all parties. Sometimes an OPA or DDA will be entered into with the intent of facilitating a perhaps more covert price fixing conspiracy. But even where this is not the case there is ample experience to indicate that the anticompetitive consequences of OPA $s$ and DDA $s$ can be substantial.

Even where parties enter into an OPA or a DDA with the intent of achieving the same price levels as could be attained through direct price fixing (as will often be the case), it is not strictly correct to characterize the agreement as price fixing. There is a clear conceptual difference between an agreement to quote certain prices and one to exchange data or quote only "public" prices, which in certain market structures may result in pricing behaviour similar to that associated with a traditional price fixing conspiracy. Failure to make such a distinction can result in considerable confusion for both the enforcement authorities and the courts. Another source of confusion in this area is evidentiary: market behaviour such as sudden price uniformity, often viewed as evidence of price fixing, is also consistent with an OPA or DDA. Likewise, the motivation for entering into any of three types of agreements, viz, the achievement of price stability, will often be similar. Apart from the evidentiary problems there is considerable uncertainty in the law itself, at least as it relates to OPA s and DDA s.

While there is a long chain of American decisions concerning the legality of OPA $s$ and DDA $s$, in Canada this issue has arisen only recently, largely as a result of two cases, $R$. v. Armco Canada Ltd. ${ }^{3}$ and $R$. v. Anthes Business Forms Ltd.4 Unfortunately, while the problems of open pricing and data dissemination have certainly been raised in these two cases, they have not been resolved, either in terms of competition policy or in terms of articulating the law.

\section{OPENING PRICING AGREEMENTS}

\section{A. The Effects on Competition}

It is important to properly characterize the nature of an agreement in issue. Under an OPA (as I have defined it), the agreement is not to fix prices, nor to follow a price leader, but simply to publicly announce prices, and to adhere to these public or open prices in individual trans-

3. (1974) 17 Can. Pat. R. (2d) 211 (Ont. H.C.); affd sub. nom Re the Queen and Armco Canada Ltd. (1976) 24 Can. Pat. R. (2d) 145, 70 D.L.R. (3d) 287 (Ont. C.A.); leave to appeal to the Supreme Court of Canada refused [1976] 1 S.C.R. vii.

4. (1974) 16 Can. Pat. R. (2d) 216 (Ont. H.C.); affd (1975) 20 Can. Pat. R. (2d) 1 (Ont C.A.); (1977) 28 Can. Pat. R. (2d) 33 (S.C.C.) 
actions. In theory, at least, it is possible for pricing behavior to be competitive, as long as the publicly announced prices are arrived at in a competitive manner. One type of competition that will be eliminated as a result of such an agreement is the practice of giving secret off-list discounts in privately negotiated contracts or in bidding below a firm's publicly announced list prices on contracts let out to tender. Thus, the only type of competition possible is that based upon "open" or public list prices.

However, if the market in question is oligopolistic,5 such "open pricing", while not collusive in the legal sense, may be characterized by "conscious parallelism" and price leadership. The dynamics of "conscious parallelism" have been extensively analyzed elsewhere ${ }^{6}$ and need only be recapitulated here. Consider the phenomenon of price leadership. A price leader in an oligopolistic market raises its prices to a level above that which would be attained if the market were truly competitive. The price leader in so raising its price does so on the assumption that all its rivals will engage in identical or parallel pricing behaviour. This assumption is not unreasonable; if its rivals are rational they will forego any short-run profits which they could acquire by not following the price leader (in terms of customers which they could glean from the leader, 7 in favour of the long-run profits associated with an increase in the industry wide price. Because such pricing behavior takes into account the likely reactions of competitors it is often described as "interdependent" (as opposed to the independent behavior of firms in the so-called perfectly competitive market which price at market, without taking into account rivals' reactions).

While interdependent pricing behavior may be rational, sometimes even a rational oligopolist might succumb to greed in an attempt to acquire a bigger market share by shaving or "chiselling" its openly announced prices unsystematically.$^{8}$ Such behavior might very well be counter productive if done openly. Because its rivals know of the prospective discount, they will be in a position to meet the price quotations of the discounter. Even worse from the viewpoint of the discounter is the possibility that rivals will retaliate. In addition, there

5. An oligopolistic market is traditionally defined as one in which there are few sellers and a relatively homogenous product.

6. See, in particular, Turner, "The definition of agreement under the Sherman Act: Conscious parallelism and refusals to deal", (1962) 75 Harv. L.R. 655. For an analysis of both the economic theory of conscious parallelism and a review of Canadian cases involving the concept see Stanbury and Reschenthaler, "Oligopoly and conscious parallelism: Theory, policy and the Canadian cases". (1977) 15 Osgoode L.J. 617.

7. Such profits would necessarily be short-run, since the price leader would soon have to lower its prices to remain competitive. If the price leader, instead of immediately raising its price, announced that it would be raised, effective at a future date, there would be even more incentive for rivals to follow with similar announcements. A rival would know that if it did not follow, the price leader would simply retract its rise before it had become effective. If this happened there might not be an opportunity to "steal" customers, even in the short-run.

8. This chiselling or discounting would be counter-productive if done across the board. Yet firms can be expected to engage in it, perhaps to get a new customer, or a very large buyer, or a particularly hard bargaining buyer. If done on a systematic basis it may raise problems in respect of price discrimination. See R.S. Nozick, "The regulation of price discrimination under The Combines Investigation Act", (1976) 54 Can. Bar Rev. 309 at 328-29. 
may be demands from other customers for an equivalent discount. These latter two possibilities may very well cause a fall in market wide published prices. Hence, there is a need for secrecy in such off-list transactions or bids. ${ }^{9}$

An early example of an American opening pricing arrangement attacked under antitrust laws was considered in Sugar Institute v. United States.10 The agreement in that case was implemented by the mechanism of a trade association, the Sugar Institute. The 15 defendant companies refined almost all the imported raw sugar processed in the United States and accounted for $70 \%$ to $80 \%$ of the sugar consumed. The product was thoroughly standardized. Prior to the organization of the Institute some of the refiners had developed the practice of giving secret concessions. These refiners were regarded as "unethical":"1

The need of secrecy was urgent, for as soon as it was known that a specific concession was granted it would be generally demanded. That concessions were widely granted was generally known in the trade, and while each refiner was able to find out in a general way the approximate prices and terms of his competitors, it was impossible to know with any degree of accuracy the actual prices and terms granted in the innumerable transactions.

Largely as a result of this type of behavior, the parties agreed that sugar should be sold only upon open prices and terms publicly announced. The effect of such an agreement should be understood in light of the practice in that trade of selling on "moves". A "move" was a public announcement of a price rise to take effect at a future date. Prior to that date, sugar could be purchased at a lower price. However, the defendants admitted that: 12

$\ldots$ in actual practice the initial announcement might be made by any one of the refiners and that the move actually takes place only if all refiners follow a similar course. If any one fails to follow with a like announcement, the others must withdraw their advance, since sugar is a completely standardized commodity.

The Court found that ". . . the unreasonable restraints which defendants imposed lay not in advance announcements, but in the steps taken to secure adherence, without deviation, to prices and terms thus announced." 13 It is noteworthy that the agreement was not treated as an instance of price fixing, which in the United States is illegal per se.14 In large measure, the practice was banned because this particular industry was highly oligopolistic, and because sugar was a standardized commodity in which price competition as opposed to brand com-

9. This is, incidentally, a good reason why the winning tender price ought not to be openly announced. Where the winning bid is kept secret, some firms might be willing to discount their list prices. After all rivals might well attribute the winning bidder's success not to discounting, but to being picked at random, a not unknown practice where the bids are identical. See D.L. McLachlan, "Monopoly and collusion in public procurement: A survey of recent American experience". (1976) 8 Antitrust Law and Ec. Rev. 69 at 76. Many public bodies, however, are required by statute to publicly make known all bids; this supposedly reduces the possibilities for corruption of public officials. See e.g. The Public Works Act, R.S.A. 1970, c. 303, s. 6(2).

10. (1936) 297 U.S. 553.

11. Id. at 574 .

12. Id. at 580 .

13. Id. at 582 .

14. See e.g. U.S. v. Trenton Potteries Co. (1927) 273 U.S. 392; U.S. v. Socony.Vacuum Oil Co. (1940) 310 U.S. 150. 
petition is paramount. "The fact that ... there was a strong tendency to uniformity of price, makes it even more important that such opportunities as may exist for fair competition should not be impaired."15

While the defendants claimed that the agreement prevented discriminatory practices against buyers, other analysts of the case treat the agreement as one which "... inevitably intended to check general price reductions. By eliminating all concessions the plan deprived individual buyers of an opportunity to negotiate on prices, a useful practice in markets of imperfect competition."16

In sum, agreements to adhere to publicly announced prices facilitate that mutually interdependent pricing behavior known as conscious parallelism. For effective conscious parallelism to exist, competitors must have information about their rivals actual, and not just published, prices. By prohibiting deviations from public or list prices that one element of uncertainty, the possibility of secret discounts by rivals, is removed from the factors which a competitor must take into account when setting its prices. In markets which are oligopolistic and in which the product is standardized, publicly quoted prices could be expected to be both identical and non-competitive (in the sense of being set by competitors interdependently). However, actual prices on individual transactions may differ from public or list prices. As Sugar Institute illustrates, such secret discounts, while often characterized by competitors as "unethical", are in fact a form of competition. It is true that this competition is not that of the purely competitive auction markets of economic theory (in which the market sets the price which all firms must follow); however, in certain market structures it may be the only type of competition that can be realistically expected to exist. Open pricing arrangements effectively eliminate this form of competition.

\section{B. Regina v. Armco Canada Ltd. ${ }^{17}$}

The Armco case illustrates both the confusion that can arise when parties claim they were "merely" engaging in "open pricing", and the very practical danger that the very act of so professing can constitute circumstantial evidence of actual price fixing.

The accused, charged under s. 32 of the CIA raised the issue of open pricing in the Armco case. The case indicates that there is a very fine line indeed between competitors independently (or perhaps interdependently) deciding to "open price", and agreeing to adhere to openly announced prices, and between open pricing (whether arrived at with the aid of an agreement or not) and a traditional price fixing conspiracy.

The Corrugated Metal Pipe Institute ("CMPI") was incorporated on November 10, 1961 with the purported aim and object of promoting the general use of corrugated metal pipe and providing the public with

15. Sugar Institute v. United States (1936) 297 U.S. 553.

16. Stocking, "The rule of reason, workable competition and the legality of trade association activities" (1954) 21 U. Chic. L.R. 527 at 579-580.

17. R. v. Armco Canada Ltd. (1974) 17 Can. Pat. R. (2d) 211 (Ont. H.C.): aff'd sub. nom $R e$ the Queen and Armco Canada Ltd., (1976) 24 Can. Pat. R. (2d) 145, 70 D.L.R. (3d) 287 (Ont. C.A.); leave to appeal to the Supreme Court of Canada refused [1976] 1 S.C.R. vii. 
data about the comparative merits of corrugated metal pipe and drainage structures.18 According to a letter from the President of the CMPI on March 22, 1963 the industry at that time could be characterized as one operating at $30 \%$ capacity with low barriers to entry (in terms of needed capital). There were 22 companies with 49 plants as opposed to 15 companies with 37 plants in 1957.19 Price competition was vigorous. 20

The subject of an "open price policy" was first raised at a November 21, 1962 meeting of the CMPI by a director of the CMPI, who was requested to provide background information about open pricing. As a result, a letter was circulated to the directors of the CMPI outlining both the meaning and objectives of open pricing. According to this letter open pricing meant "... that each firm [would] openly set out its prices in written or printed form, including discounts, terms of credit, and make these available to all customers, competitors and the public."21 The letter clearly outlined the objectives that could be attained by the adoption of an open pricing policy: "The industry will have established an ethical standard which is fair to one and all . . . An Open Pricing Policy will tend to stabilize prices at a competitive level, allowing management to forecast results ahead ... Price lists themselves are valuable Public Relations and Advertising tools."22 While couched in diplomatic language, it, is evident that the prime objective was to put an end to the cut-throat price competition. However, the letter also indicated that: 23

Each company's price list must be entirely its own arrived at independently without agreement or coercion with anyone. There must be no understanding, tacit or otherwise, that lists are inflexible, and decisions to change or revise lists must again be an individual company responsibility. [Emphasis in original]

Following the circulation of this letter at a CMPI meeting on February 18,1963 , members were addressed about industry problems resulting from unbridled competition:24

When competition is unintelligent, it can be one of the most destructive forces and no theory of economics nor any law in the country requires unintelligent competition. Any businessman is entitled as a matter of law to obtain if he can all the facts about anything he may want to know in order to base his own individual judgment on intelligent thinking rather than blind reaction. . . You are entitled to use those facts in the formulation of your own merchandising decisions (open price lists) but you are not entitled to use them with your competitors in the formulation of joint merchandising decisions however intelligent they may seem. [Emphasis in original]

It is apparent that until this time various individuals associated in one way or another with the industry were attempting to prompt or

18. Supra n. 2, at 10.

19. R. v. Armco Canada Ltd. (1974) 17 Can. Pat. R. (2d) 211 (Ont. H.C.) at 218.

20. This is evidenced by data in respect of tenders to the Ontario Department of High. ways. In the fiscal year $1962-63$ in $44.5 \%$ of all contracts the lowest bid was accepted. In the fiscal year 1963.64 this figure rose to $81 \%$. There was also "... a great variety of quotations of prices from all bidders ... Id. at 217 .

21. Id. at 220 .

22. $I d$. at $220,221$.

23. This quotation was from an address by an executive of the Steel Warehousing Associa. tion defining "Open price policy", which was included as an enclosure with the letter. Id. at 222.

24. Id. at 226. 
educate members to engage in a pattern of price leadership which had not previously developed spontaneously within the industry. As witness the care taken in the language employed, it was realized by all concerned that such a pricing pattern (if it were to develop in the industry in a manner that would not risk prosecution under the CIA) would have to be arrived at independently by each of the members, i.e. without the aid of an agreement or arrangement. However, those seeking to prompt such a policy were confronted with a dilemma: the industry in the past had not independently fallen into a pattern of price leadership, yet they could not agree or arrange to do so. The documentary evidence evinces an intention to stay on the proper side of that fine line between agreement and non-agreement by attempting to educate and explain the benefits of independently arrived at open pricing. Obviously this raises the important factual issue of precisely when that fine line between education and arrangement is crossed as well as the legal question of what precisely is meant by arrangement or agreement. In fact, D.H.W. Henry, then Director of Investigation and Research of the Combines Investigation Branch, had earlier written a letter (which was distributed to Institute members) about the prospects of implementing an open pricing policy in the steel warehousing industry (of which several of the accused were also members) in which he wrote that: 25

It seems to me that once the activities of the Association go beyond education and take the form of direct persuasion and implied coercion of individuals, it can scarcely be said that the industry members have independently adopted the policy in question.

On May 2, 1963 the CMPI passed a resolution stating that "potential benefits could be derived by individual members of the industry from the adoption of the open pricing policy".26 Then, in June, 1963, Robertsteel, one of the accused, published an "open price list". This apparently did not result in any stabilization of price competition.27 In September, 1963 a report prepared by two executives of suppliers of steel used to make culverts was circulated to institute members. This report, called the Craig-Allan Report, reiterated the evil of price cutting and, in the opinion of the Court, urged ". . . an agreement without appearing collusive $\ldots .{ }^{28}$ In particular the report stated:29

- Managements must immediately initiate within their own sales organizations the practice of adhering to their published prices [My emphasis] . . .It should be possible with a series of changes in published prices and appropriate leadership by certain management relative there to that proper price levels ... can be achieved ... [Emphasis in original]

(The report also advocated the implementation of delivered pricing as opposed to FOB plant pricing. FOB pricing makes price uniformity difficult to achieve whether such uniformity is normally obtained by collusion or by a non-collusive pattern of price leadership. If all firms quote the same FOB price, the buyer will select the seller closest to

25. Id. at 229 .

26. Id. at 230 .

27. This stabilization did not occur because the industry leader, Armco., had a technological advantage in the production of helically formed pipe. Armco was apparently not willing to give up this advantage at that time. See Id. at $233-234$.

28. Id. at 238.

29. Id. 
it.30 On the other hand, if a firm quotes only delivered prices to buyers within a given geographic area, and if other firms, whether as a result of collusion or otherwise, adopt the same base point price, the price to the buyer will be the same regardless of the fact that it buys from a firm more proximate to it. This practice was specifically condemned by the RTPC as being discriminatory to buyers and economically wasteful.31)

In December, 1963 price uniformity was suddenly achieved. On December 2, 1963 Robertsteel published a new price list and by December 13, 1963, ". .there was general acceptance of Robertsteel price lists by all bidding manufacturers with uniform or identical bidding which was contrary to what had previously existed".32 This uniformity in pricing by competitors of Robertsteel occurred prior to these firms publishing new price lists. The Crown submitted statistical data showing marked increases of uniform bidding when business was put out to tender. ${ }^{33}$

Mere uniformity in pricing is not in itself price fixing nor is it necessarily conclusive evidence of price fixing. There appear to be three possible explanations of the sudden uniformity in pricing:

1. There was an agreement to fix prices. In the context of the industry in question this could amount to an agreement to follow the price leader in all price quotations.

2. There was no agreement or arrangement to follow the price leader, but there was an arrangement to adhere to whatever prices had been publicly announced via the price lists.

3. There was no agreement whatsoever. Rather the decisions to follow Robertsteel's price lists and the decisions not to deviate from price lists were made independently, although perhaps interdependently.

The essence of the accused's contention was that this pattern of identical pricing occurred solely as a result of conscious parallelism, and that efforts made to educate participants about the benefits attainable by conscious parallelism and open pricing fell short of amounting to an agreement or arrangement. The Court rejected this contention and found that the accused was guilty of an arrangement under s. 32.34 While, at one point, the trial Judge stated that, ". . .there had to be

30. Thus less proximate firms will have to shave their prices in order to compete. In this way F.O.B. pricing makes uniform pricing difficult to achieve.

31. Supra n. 2 at $51 \cdot 52$.

32. R. v. Armco Canada Ltd. (1974) 17 Can. Pat. R. (2d) 211 at 241.

33. Id. at $243-251$.

34. A most interesting facet of the case was the legal definition of arrangement apparently adopted by Lerner J. He quoted the definitions from Wilmer L.J. and Diplock L.J. in British Basic Slag Ltd. v. Registrar of Restrictive Trading Agreements [1963] 1 W.L.R. 727 at pages 739 and 747 respectively:

For when each of two or more parties intentionally arouses in the others an expectation that he will act in a certain way, it seems to me that he incurs at least a moral obligation to do so. An arrangement as so defined is therefore something "whereby the parties to it accept mutual rights and obligations".

No necessary or useful purpose would be served by attempting an expanded and comprehensive definition of the word "arrangement" in section 6(3) of the

(Con't next page.) 
an understanding, arrangement or agreement to adopt the open price policy",35 it seems clear that he meant an agreement to actually fix prices, i.e. my first explanation. This is made clear several times in the judgment: 36

It would offend one's common sense to come to any other conclusion but that there was deliberate, painstaking agreement and effort on the part of these several companies in these pertinent years of equal prices on all items ...

There had to be at least a tacit if not direct agreement between the producing members of the Institute to tender from price lists consisting of identical or equal prices.

It would offend one's common sense ... not to arrive at the irresistible conclusion ... that an arrangement was finally achieved between the members of the Institute to have ... price "leadership" and "followership"...

The RTPC Report is not quite so specific. The RTPC defined the issue as follows: ${ }^{37}$

... it is necessary to keep clearly in mind the distinction between "open prices" and "Open Price Policy". The practice of each manufacturer publishing a price list had been followed for many years in the metal culvert industry. The essential feature of the "Open Price Policy" as adopted by the metal culvert manufacturers involved in the present inquiry is that prices would be published and that the manufacturer would make clear his intention of adhering to the published prices as long as competitive conditions did not require different prices. The result when all manufacturers in the market area adopted the prices of the "price leader" and adhered to them was that price competition was removed from the market. The point at issue, therefore, is whether the non-competitive situation was brought about by the independent action of different manufacturers or whether it came about from an agreement, arrangement or understanding between the manufacturers. [My emphasis]

\section{After considering the evidence the RTPC concluded: ${ }^{38}$}

. . the Commission has come to the conclusion that the adoption of common prices in the manner described earlier in this report demonstrates a mutuality of action by the producers named in the Director's allegations which amounted to an arrangement within the meaning of the Combines Investigation Act. The effect of the arrangement was to establish uniform prices and conditions of sale for metal culverts by all producers named in the allegations. [My emphasis]

Certainly, the RTPC's conclusions, while admittedly ambiguous, are consistent with my second explanation. There is, however, ample

Act."As I see it all that is required", said Cross J., L.R. 3 R.P. 178, 196, "to constitute an arrangement not enforceable in law is that the parties to it shall have communicated with one another in some way, and that as a result of the communication each has intentionally aroused in the other an expectation that he will act in a certain way". I think that I am only expressing the same concept in slightly different terms if I say without attempting an exhaustive definition, for there are many ways in which arrangements may be made, that it is sufficient to constitute an arrangement between $A$ and $B$, if (1) A makes a representation as to his future conduct with the expectation and intention that such conduct on his part will operate as an inducement to B to act in a particular way, (2) such representation is communicated to $B$, who has knowledge that $A$ so expected and intended, and (3) such representation or A's conduct in fulfillment of it operates as an inducement, whether among other inducements or not, to B to act in that particular way.

This would mark a radical departure from traditional notions of what constitutes a conspiracy under the CIA. The Ontario Court of Appeal, at 152-155, however, disapproved of this definition because $s$. 32 requires that "... there must be the mutual arriving at an understanding or agreement, and under the British Basic Slag test, this element of mutuality is not necessarily present". The Appeal Court was not, however, prepared to allow the appeals of the accused on this ground since it was apparent that the findings of Lerner J. would satisfy more orthodox definitions of conspiracy. The appeals of three of the eleven accused where allowed on other grounds.

35. Id. at 271 .

36. Id. at 247, 251, 259.

37. Supra n. 2 at 54.

38. Supra n. 2 at 57. 
evidence to support the finding of an actual price fixing conspiracy. The court particularly emphasized the fact that competitors almost instantaneously followed Robertsteel's price list in tender quotations, in some cases even before their own price lists had been changed. This was considered especially important in the light of the fact that a similar attempt by Robertsteel had failed in the past. ${ }^{39}$ The similarity of the tenders themselves was also evidence although this is also consistent with an agreement to adhere to publicly announced prices. Finally:40

It was not only discussions within the Institute and the documents relating to open price policy that were significant, but it was the pains with which the documents, meetings, speeches, and consultations with the director of the Combines Investigation Branch were arranged, all having a cumulative bearing on what Robertsteel attempted in June, 1963.

The Armco decision illustrates several points. The first is the confusion surrounding the phrase "open pricing". What the accused meant by "open pricing" was independent decisions to adhere to public prices, which would have the effect of facilitating conscious parallelism. What the Court meant by the phrase was an agreement to adhere to published prices and to follow a price leader. Yet, there is a third meaning which can be given to the phrase, namely, an agreement to adhere to published prices, without any agreement as to price leadership, albeit price leadership may be an inevitable consequence of such an agreement.

The second point is that where the evidence is circumstantial, all three meanings of "open pricing" can serve as plausible explanations of identical pricing and tenders over a period of time. Given the criminal burden and standard of proof, and assuming that "mere" agreements to adhere to public prices are to be treated differently from traditional price fixing conspiracies, this can present the Crown with almost insurmountable evidentiary difficulties (although because of the peculiar facts it did not in the Armco case itself). These evidentiary difficulties are only heightened by the perhaps impossible task of judicially articulating the distinction between some forms of "tacit agreements" and conscious parallelism. In the words of one American writer:41

39. R. v. Armco Canada Ltd. (1974) 17 Can. Pat. R. (2d) 211 (Ont. H.C.) at 259, 260. The main holdout to that point in time had been Armco. Upon the second publication of a new price list by Robertsteel, Armeo gave up its policy of granting volume discounts and discounts on helically formed pipe.

40. Id. at 263. This is somewhat ironic. Presumably, had the accused not consulted with the Director of the Combines Investigation Branch about what was legal and illegal, not issued memoranda (which could later be seized as evidence) about the sad state of the metal culvert industry and about the benefits of open pricing and price leader. ship, and had the meetings among the accused taken place secretly, then the evidence would have been far less compelling. In attempting to openly straddle that fine line between legality and illegality, the accused firms merely emphasized both a motive which they might have for entering into a conspiracy and the lengths they were prepared to go to achieve their objectives.

It might very well be that the accused thought their conduct was legal. The evidence in the case was circumstantial. The finding of the court, at 265, was of a "tacit agreement to maintain identical prices". Yet, the legal distinction between some "tacit agreements" and conscious parallelism (which the accused alleged was responsible for the identical pricing behaviour) has never been satisfactorily articulated. See infra $\mathrm{n} .41$ and accompanying text.

41. Turner, supra n. 6 at 683 . Turner did, however, conclude that the legality of such "agreements" (interdependent behaviour) should be based on other considerations. 
Once one goes beyond the boundaries of explicit, verbally communicated assent to a common course of action - a step long since taken and from which it would not seem reasonable to retreat - it is extraordinarily difficult if not impossible to define clearly a plausible limit short of interdependence.

If nothing else, the Armco decision illustrates both the dangers and futility of competitors seeking advice on ways and means of achieving conscious parallelism. It is easy to state that conscious parallelism arrived at without the aid of an agreement is not illegal. However, where it is uncertain in law what sort of market conduct can be said to constitute a "tacit agreement", the advice becomes meaningless. It is unwise to inch forward to that fine line that demarks legal from illegal conduct, when none can see precisely where that line is, not to mention the possibility of adverse inferences being mistakenly drawn from such conduct even where competitors were in fact on the "right" side of that line.

It is unfortunate that because of the findings of fact, neither the trial Judge nor the Ontario Court of Appeal commented on the legality of "mere" OPA's. To the extent that the Armco decision is predicated on a finding of an actual price fixing agreement, it is unexceptionable.

\section{The Legality of Open Pricing Agreements Under the Combines Investigation Act}

While the Armco decision throws no light upon the matter, the legality of agreements to adhere to open or published prices must still be considered. Because of the absence of any Canadian decisions directly on point, the analysis that follows is necessarily speculative. There are two sections of the CIA to be considered: s. 32.3 (bid-rigging) and s. 32(1) (general prohibition against agreements in restraint of trade).

Section $32.2(1)$ reads:

In this section, "bid-rigging" means:

(a) an agreement or arrangement between or among two or more persons whereby one or more of such persons agrees or undertakes not to submit a bid in response to a call or request for bids or tenders, and;

(b) the submission, in reponse to a call or a request for bids or tenders, of bids or tenders, that are arrived at by an agreement or arrangement between or among two or more bidders or tenderers,

where the agreement or arrangement is not made known to the person calling for or requesting the bids or tenders at or before the time when any bid or tender is made by any person who is a party to the agreement or arrangement.

Under an OPA the bids submitted by any party to such agreement will be determined by its published or list prices; this would be an independent decision of each firm. To be sure, the agreement does restrain each of the firms from deviating from its published prices. As has been pointed out, such an agreement, together with interdependent pricing behavior, may have the same consequences as if the firms had actually agreed on what precise bids each sould submit. Nevertheless, it is doubtful whether such bids can be said to have "been arrived at by agreement or arrangement" among the tend- 
erers.42 An OPA, after all, does not specifically refer to any particular transaction or quotation. Also, it is possible, at least theoretically, for there to be competitive bidding or tendering, even where an OPA exists and is compiled with by the parties. Such a possibility would simply require different published prices. (This could happen if there was some product differentiation, but would be extremely unlikely if the product was thoroughly standardized.) 43

Assuming that an OPA does not violate the bid-rigging prohibition, can it violate section 32(1)? Because the Armco decision itself seems so broadly based on a finding of actual price fixing it cannot be used as authority for such a conclusion. The issue is a novel one in Canada. Almost all Canadian jurisprudence on $\mathbf{s . 3 2 ( 1 )}$ has dealt with situations involving actual price fixing or market allocation schemes. In spite of this, it is probable that such an arrangement would fall within $s .32(1)$. Section $32(1)(c)$ and (d), the relevant subsections, make no reference to price fixing as such. They do refer to arrangements or agreements which ". . . prevent, or lessen, unduly, competition ..." and which "... otherwise restrain or injure competition unduly ..." (s. 32(1)(c)(d).

OPA s do prevent or restrain competition of a certain type, namely, the secret concession. The real question is whether such competition has been restrained "unduly". The word "unduly" in this context has received much judicial attention. It now seems to be well established that whether or not competition has been restrained unduly is to be decided by a quantitative, and not a qualitative, criterion, i.e. how much competition has been eliminated.44 (This means that the relevant criterion in determining whether the threshold of "undueness" has been reached is the percentage of the relevant market that would be affected by the agreement if it were to be carried into effect.) Historically, there have been two strains of jurisprudence on just what quantum of lessening of competition was required to constitute "undueness". The orthodox view was that "undueness" was reached only if the parties to the agreement were in fact free to carry on their

42. Interestingly, the definition of bid-rigging in s. 32.2(1)(b) requires not merely an agreement, but the carrying out of such an agreement. This arises as a result of the words ". . . the submission ... of bids or tenders ..."

S. 32.2(1)(b) should be contrasted with s. 32.2(1)(a), which only requires an "agreement or arrangement ... not to submit a bid" and with s. 32(1), the basic conspiracy section of the CIA, in which the offence is in the agreement or conspiracy itself.

Thus a conspiracy to fix bids, as opposed to one deciding who is to bid, if discovered before it is carried out, would not be an offence under s. 32.2. It might, however, still be an offence under the more general prohibition found in $\mathrm{s} .32(1)$.

Aother peculiarity of the bid-rigging definition is the saving wording "... where the agreement or arrangement is not made known to the person calling for or requesting the bids or tenders at or before the time when any bid or tender is made. . " It is difficult to see the application of such a saving clause. Presumably the goal of the conspiracy would be frustrated if the person calling for tenders knew about it in advance. Such a saving provision is also somewhat misleading: informing the person calling for tenders of a conspriacy would not be a defence to a prosecution under s. 32(1). Historically, though, because of the need to prove the requisite element of undueness, it has been more difficult to prosecute bid-rigging conspiracies. E.g., $R$. v. Beamish Construction Co. Ltd. (1967) 65 D.L.R. (2d) 260 (Ont. C.A.). Presumably, this is why a separate offence of bid-rigging was enacted.

43. See, Sugar Institute v. U.S. (1936) 297 U.S. 553 at 574.

44. On this point see generally Gosse, The Law of Competition in Canada, (1962) $118 \cdot 142$. 
activities "... virtually unaffected by the influence of competition. .."45 The Howard Smith Paper Mills case 46 is usually thought to be the high water mark of this theory. Some subsequent decisions deviated from this rather stringent test and, while still maintaining the quantitative aspect of the test, purported to establish that competition could be restrained unduly even if competition was not virtually extinguished.47 However, it never was clear (even under this more liberal test) just how much competition had to be prevented or lessened to establish "undueness". In the 1975 amendments to the CIA ${ }^{+8}$ Parliament clearly adopted a more liberal test. Section $32(1.1)$ reads:

For greater certainty, in establishing that a conspiracy, combination, agreement or arrangement is in violation of subsection (1), it shall not be necessary to prove that the conspiracy, combination, agreement or arrangement, if carried into effect, would or would be likely to eliminate, completely or virtually, competition in the market to which it relates or that it was the object of any or all of the parties thereto to eliminate, completely or virtually, competition in that market.

The rather peculiar wording of this amendment does not establish a threshold for the point at which an agreement becomes "undue". It simply negates the stringent Howard Smith Paper Mills test. Indeed, the retention of "unduly" in s. 32(1) clearly established that at least some agreements to lessen competition will not be illegal. The question of what "unduly" does mean still exists.

In applying the quantitative test of "undueness" to OPA $s$ it is quite probable that some such arrangements will not be found to be "undue". The quantum of competition reduced between competitors is that competition for sales that would normally be secretly negotiated or by way of submission of tenders. Yet, these types of sales might in certain markets form only a small percentage of total sales volume. Consider the following example.

In a given year in a market it is found that $75 \%$ of sales are made directly by quotation of list prices. $15 \%$ are made by tenders or bids in response to a call for tenders, in which the bids are often below list prices. The last $10 \%$ of sales are made by negotiated contracts at discounts off list prices. There is no agreement whatsoever. At the end of the first year the firms agree to adhere to published prices. Because of this agreement there are no secret discounts and all bids in response to calls for tenders are those published via price lists. Competition has thus been effectively restrained to the extent of $25 \%$ of sales. Yet, since there is no restraint on what price lists to adopt there is still competition in respect of the $75 \%$ of sales which have always been made on a "list" basis. 19

45. Howard Smith Paper Mills v. The Queen [1957] S.C.R. 403 at 426.

46. Id.

47. See in particular, R. v. Canadian Coat and Apron [1967] 2 Ex. C.R. 53 at 63, and the dissenting judgment of Laskin J.A. as he then was, in $R$. v. Beamish (1967) 65 D.L.R. (2d) 260 at 285 .

48. S.C. 1974 - 75 - 76 , c. 76 s. $14(2)$.

49. As a result of conscious parallelism such list prices might be identical. In the economic sense of the word such pricing behaviour would not likely be regarded as competitive. Yet, in the legal sense, the way list prices are arrived at is competitive in that they are set non-collusively. 
It is, at the very least, arguable that a reduction of competition of $25 \%$ is not undue. Hence, it may very well be that the legality of OPA $s$ depends in part upon the percentage of sales for which one could normally expect some discounting. ${ }^{50}$

\section{Evaluation of the Law and Proposals for Reform}

The present state of the law as it relates to open pricing agreements is unsatisfactory in two respects. First, as is the case with so many areas of combines law, both the law and its application are unclear. It is conceivable, but unlikely, that OPA s may fall outside the scope of the CIA entirely. If such agreements do fall within the purview of the legislation, it seems certain that not all OPA s are illegal.51 Precisely under what circumstances open pricing agreements are illegal is an element of uncertainty not desirable in the criminal law.

Secondly, whether or not some or any OPA s are illegal, all such agreements ought to be prohibited per se. In deciding whether our competition policy is furthered by a per se prohibition, the following criteria, suggested by Kayser and Turner, are useful:52

The substantive justification of a per se rule must rest on the fact or assumption that the gains from forbidding the specified conduct far outweigh the losses. The magnitude of this difference, plus the administrative gains, must be enough to justify the element of arbitariness which is always involved. This requires, first, that the harmful effects of the practice be significant; and second, either that they depend to a great enough extent on the outlawed practice so that they cannot be easily achieved in other ways, or that such ways can be anticipated and also be forestalled by per se rules. If these conditions are met then one of three further conditions must be met:

1. The condemned practice is always harmful. ..

2. The practice is sometimes harmful and sometimes neutral, but never contributes positively to the working of the market. .

3. The practice is sometimes harmful, sometimes neutral, and sometimes beneficial, but the aggregate of harm... far out weighs the aggregate of benefit...

Applying the above criteria to OPA $s$ the damage to competition is significant, there are no beneficial effects, and the practice is readily definable. Prohibiting such agreements per se would also have the additional advantage of making the law more certain.

In spite of the desirability of a per se prohibition one cannot be too optimistic that it will evolve through judicial interpretation of $s .32(1)$ (after all, the Supreme Court has recently affirmed that not even all price fixing agreements are prohibited per $s^{33}$, or through legislative

50. One possible way to circumvent an argument of the above type is to allege a very narrow relevant market. E.g., if the relevant market in which it is alleged competition has been restrained unduly is a geographic area in which all sales were effected by calls for tenders, or perhaps only one buyer such as a government department, then the quantum of lessening of competition in the market will be a higher percentage and thus, arguably, undue. Such market "gerrymandering" would not, of course, necessarily have to be accepted by the Court.

51. Supra n. 49 and accompanying text.

52. Kaysen and Turner, Antitrust Policy (1965) 143.

53. In Aetna Insurance Company v. Queen [1978] 1 S.C.R. 731, (1977) 75 D.L.R. (3d) 332, the Supreme Court of Canada allowed an appeal from a conviction involving an admitted price-fixing agreement among some 73 insurance companies in Nova Scotia. The main ground for allowing the appeal was that the trial Judge had found that the necessary element of undueness had not been proved. 
amendment.) ${ }^{54}$

\section{DATA DISSEMINATION AGREEMENTS}

\section{A. Effects on Competition}

Whereas the effects of OPA $s$ are direct, obvious and always anticompetitive, the competitive effects of DDA s are more elusive. Nevertheless, at least in some circumstances, DDA s can cause substantial harm to competition, either by the facilitation of conscious parallelism or through their use in conjunction with a price fixing conspiracy. DDA s can vary considerably in their terms, from vague arrangements to supply rivals with current prices if asked ${ }^{55}$ to formal written agreements involving the immediate submission of reports on individual transactions, with provisions for audits to ensure truthfulness and accuracy. ${ }^{56}$ More often than not, a trade association will be the mechanism through which a DDA is implemented. The potential damage to competition which a DDA can cause will depend in large part on its precise terms and on the nature of the market in which the parties to the agreement operate.

The perfectly competitive market of economic theory has been described as follows: ${ }^{57}$

... [A]s the economists have conceived it the buyers and sellers of a standardized commodity are so numerous and so well informed that none has any influence on the price for which the product sells. Sellers are free to sell or withhold their products from the market as best suits the interest of each. Buyers are free to buy or to refrain from buying according to their several judgments. But sellers who sell and buyers who buy do so at identical prices at any moment of time. The prevailing price is one at which the amount offered equals the amount which buyers will take. It clears the market. It is the equilibrium price of the economic theorists.

Needless to say, the assumptions on which this theoretical model is based rarely exist. Many markets are not atomistic, many products are not standardized, and buyers and sellers are not always well informed. It is the absence of complete information which is of concern here, for proponents of DDA s usually argue that the exchange of data (particlarly in respect of costs and prices) makes sellers (and perhaps buyers) better informed, thus enabling the real market to more closely mirror the perfectly competitive model of economic theory, imperfect competition thus becoming less imperfect. The soundness of this argument must be examined.

54. In Bill C 256 (28th Parl. 1970 - 71), the long deceased grandfather of recent competition bills, a proposal in $s .16$ would have banned price-fixing agreements without regard to undueness. The bill was never passed. Subsequent amendments to the CIA and bills did not include a per se prohibition of price-fixing. Given this conscious decision not to prohibit price-fixing per se, not much can be expected in terms of legislative changes in respect of OPAs.

55. This was the essence of the price exchange scheme in U.S. v. Container Corp. (1969) 393 U.S. 333.

56. e.g. the DDA s utilized in American Column \& Lumber Co. v. U.S. (1921) 257 U.S. 377, and R. v. Anthes Business Forms Ltd. (1974) 16 Can. Pat. R. (2d) 216.

57. Stocking, supra n. 16 at $541-542$. 
Almost all commentators have concluded that the net effect of exchanges of pricing information (where there is identification of individual transactions and of individual buyers and sellers), even when not used as a vehicle for blatant price fixing, is to stabilize prices, resulting in non-competitive, albeit non-collusive, pricing behaviour. ${ }^{58}$ It is important to understand why this is so.Agreements of this sort have usually been adopted by sellers in markets which can be characterized as: 59

... imperfect and, though they contain large numbers of sellers and buyers, they involve significant elements of oligopoly, at least in the short run. These elements arise because geographic and product subdivision of markets tends to create subgroups of sellers whose price and output decisions react more immediately on each other than on the market as a whole.

We have seen how in at least some oligopolistic markets there is a tendency to interdependence and conscious parallelism and how the possibility of secret off-list discounting can serve as an important impediment of such oligopolistic coordination. Firms, particularly under conditions of excess capacity, might succumb to temptation by giving discounts from published prices; this is a form of competition in itself. In addition, even where firms would otherwise have a predisposition to adhere to list prices, they might discount, if they suspect, perhaps erroneously, that their rivals are "chiselling". When many sellers behave in this manner competition based on actual, as opposed to published prices may become fierce. Under these pressures even published prices may become competitive.

Obviously, OPA s (assuming parties abide by the agreement) by definition foreclose any possibility of secret price competition. But even DDA s (which usually involve only disclosure of prices on closed transactions) can have an inhibiting effect. Underlying unsystematic discounting of the above sort is the belief of the prospective discounter that since its rivals will not know of the price cut, at least for a while, they will not retaliate. To the extent that DDA $s$ can give firms immediate information about rivals' actual prices on individual transactions, they will operate as a disincentive to discounting.

It can be seen then that an element of uncertainty in respect of competitors' prices may be essential to maintaining competition and frustrating oligopolistic interdependence. However, it should not be concluded that the effect of a price exchange scheme will automatically result in identical pricing. Depending on the extent of concentration in the market in question, the number of rivals not subject to the price reporting scheme, the precise terms of the scheme (especially the amount of time lag between transactions and reporting, whether parties are specifically identified, etc.) and the actual way in which a price reporting scheme is carried out, there might well be an absence of uniformity in pricing. But the amount and range of discounting could be expected to be less where a price reporting scheme exists. ${ }^{60}$ Fewer

58. See e.g. Kaysen and Turner, supra n. 52 at 150; Burns, The Decline of Competition (1936) 60, 61; Heath, "Restrictive trade practices legislation: Some economic consequences" (1960), 70 Econ. J. 474 at 477, 478; Scherer, Industrial Market Structure and Economic Performance (1970) 449 - 453.

59. Kaysen \& Turner, supra n. 52 at 150.

60. Heath, supra n. 58 at 478 . 
firms could be expected to take the risk of retaliation inherent in discounting, and those who would still be inclined to discount could be expected to minimize such risk by giving a lesser discount than would otherwise be the case. Quite apart from the risk factor, firms in the position of guessing what a rival is going to quote might guess wrongly and quote a price significantly lower than their competitors. On the other hand, if a firm actually knows what its competitors are going to quote or can draw reasonable inferences based on rivals' recent transactions, it may be inclined merely to meet its rivals' quotations as opposed to undercutting them.61

In some cases, of course, the dissemination of pricing data amongst competitors may be part of an underlying covert price fixing conspiracy. In this context the dissemination of data may facilitate price fixing in two ways: first, as an implementation or signalling device, and second as an enforcement and surveillance mechanism.

\section{(1) DDAs as a Signalling Device}

Where the number of competitors in a market is small and where the product to be supplied is fairly homogenous it is not likely that a formal data dissemination agreement would be necessary to communicate the agreed upon price. Parties could simply quote the agreed upon price; any market wide price changes necessitated by changes in supply and demand could easily be communicated by advance public announcement by an agreed upon price leader or by making a new agreement. However, where there is a larger number of parties to the conspiracy, and particularly where product lines are complex, or where buyers insist on product modification to suit their own needs, a more sophisticated method of determining and communicating the cartel price may be necessary ${ }^{62}$ The following description of a famous electrical equipment conspiracy of the 1950's illustrates this: 63

\footnotetext{
[The conspiracy] involved at least 29 different companies selling turbine generators, transformers, switchgears, insulators, industrial controls, condensers, and other electrical equipment with total sales of roughly $\$ 1.5$ billion annually ...

On standardized products such as insulators, standard transformers, and industrial controls, company representatives met and agreed upon prices which each promised to quote in all subsequent transactions until an agreement to change was reached. This was by far the simplest arrangement, but it suffered from the disadvantage of arousing suspicions when all firms submitted identical bids in repeated transactions. A more complex approach was required for products such as turbine generators, since each buyer demands modifications to suit his own special needs, and as a result no two orders are ever exactly alike. Collusion in this case was facilitated by the publication of a pricing formula book half the size of a Sears Roebuck catalogue. By piecing together the prices of each component required to meet a buyer's generator specifications, firms were able to arrive at the 'book price' on which discussions centered.
}

A more subtle price fixing conspiracy involving the dissemination of price lists would be one in which the agreement is not to discount more than a certain percentage off list prices. The list prices then become a

61. This was the opinion of Mr. Justice Fortas in U.S. v. Container Corp. (1969) 393 U.S. 333 at 340, about the effect of price exchanges in that case.

62. For a summary of the various ways and means of implementing price fixing conspiracies see generally Scherer, supra n. 58 at $158-164$.

63. Scherer, supra n. 58 at $159-160$. 
reference point, indicating, when accompanied by an agreed upon maximum discount, the permissible range of price quotations.64 The main advantage of such an agreement is that the pricing behaviour of the parties would be less suspicious. Price statistics over a period of time would show both discounting and differential price quotations on individual contracts; at the same time the general level of prices could be expected to be higher. It does, however, invite the breakdown of the conspiracy, should one party persistently quote prices showing the maximum discount.

\section{(2) DDAs as an Enforcement and Surveillance Mechanism}

The second and probably more important use of data dissemination agreements in facilitating actual price fixing, is as an enforcement and surveillance mechanism. What follows is an analysis of some typical terms in data dissemination agreements and the use that may be made of them in this context.

(a) Identification of Buyers and Sellers in Individual Transactions

Obviously, the identification of individual sellers in every transaction, or in every transaction at a discount from list, can serve to expose such sellers to disciplinary pressure from competitors.65 Likewise, pressure may be brought to bear upon particular buyers.

While such a practice may be conducive to collusion, it is not conclusive evidence of such collusion, even if, as a question of fact, some price stabilization has occurred. As has been noted, such stabilization can occur simply as a result of conscious parallelism which the DDA has facilitated.

The reporting and identification of offers, as opposed to closed transactions, is even more clearly fraught with danger to the public interest. It is, however, sometimes argued that such information should be available in order to allow sellers to verify buyers' allegations in respect of bids from other sellers, and thus prevent fraud.66 There are two responses to this argument. First, whether such conduct should be characterized as fraud or merely hard bargaining is debatable. Secondly, even if fraud is an appropriate description, it would seem that the dangers inherent in reporting all offers more than outweigh the harm occasioned to individuals by "phantom" competition. In any event, a prohibition against the disclosure of all offers, would not necessarily foreclose an individual seller from enforcing his civil remedies, assuming that they exist.67

(b) Distribution of Cost Statistics and Agreements on Cost Accounting

The dissemination of statistics on costs does not lend itself quite as

64. Indeed, it is possible to conceive of an even more inchoate agreement not to discount "too much".

65. See Burns, supra n. 58 at 62; Kaysen \& Turner, supra n. 52 at 150-151.

66. For an analysis of recent American jurisprudence on this issue see Note, "Antitrust liability for an exchange of price information - What happened to Container Corporations?" 63 Va. L.R. 639 at $661-663$.

67. These remedies could possibly include an action for deceit and recission of the con. tract. 
readily to price fixing as does the dissemination of pricing data. As well, industry wide cost data can serve the useful economic function of indicating to individual firms how efficient they are relative to their competitors. Nevertheless, even the distribution of cost information can be dangerous.

Kaysen and Turner have concluded that the distribution of a costaccounting scheme can be "... an ivitation to uniform mark-ups over raw material and labour costs to determine total manufacturing cost, and uniform mark-ups over cost to determine 'proper' selling prices ..."68 Burns, in an early assessment of American trade associations noted that the standardization of cost-accounting, particularly where profits are included in the definition of costs, can result in a desired selling price, but that price cutting may still very well occur because of differences among individual firms in their calculation of individual costs.69

The distribution of industry wide average costs must be viewed with great skepticism. First, it can be a signal, when taken together with an agreed upon mark-up, as to the final selling price.70 Secondly, it serves no useful economic purpose that could not be accomplished by means less capable of competitive abuse. While industry wide average costs do give the higher cost firms knowledge of their relative inefficiency, and can thus become an inducement to them to become more efficient, they do not give the low cost firms anything but the most general standard against which to compare themselves."1 Kaysen and Turner have suggested that only distributions of mark-ups, or of ratios of overhead to variable costs should be permitted.72

\section{(c) Audits and Opening Books to Rivals}

To the extent that data dissemination schemes further any legitimate purposes, it may be necessary that a trade association or other reporting agency have the power to verify by means of an audit, the information filed with it. However, audits can also be used as a surveillance mechanism in an illegal price fixing conspiracy. (The reporting scheme itself would be insufficient since price "chisellers" could file incorrect information.)

As long as the detailed information arising from the audit remains exclusively with the reporting agency, the dangers are minimized. But, if the competitors' books are directly open to rivals, or if any competitors, as a matter of course, can require the reporting agency to conduct an audit and receive or have publicized the information resulting therefrom, the danger becomes acute. In the words of one American judge: ${ }^{73}$

68. Kaysen and Turner, supra n. 52 at 152.

69. Burns, supra n. 58 at 49 et seq. He concedes that the amount of price cutting in such circumstances can be expected to decrease as standardization of methods of distributing overhead costs decrease cost differences among individual firms.

70. Burns, supra n. 58 at $50 \cdot 51$.

71. Id. at 51 .

72. Kaysen and Turnêt, supra n. 52 at 152.

73. American Column \& Lumber Co. v. U.S. (1921) 257 U.S. 377, per Mr. Justice Clarke at 410. 
Genuine competitors ... do not contract, as was done here, to submit their books to the discretionary audit and their stocks to the discretionary inspection of their rivals, for the purpose of successfully competing with them....

\section{(d) Unavailability of Information to Buyers}

The failure to make pricing information obtained through a data dissemination scheme available to customers has been commented on adversely in the United States, both in academic literature ${ }^{74}$ and in judicial decisions. ${ }^{75}$ One reason for this is that withholding information from buyers is incompatible with the usual rationalization of data dissemination schemes put forward by their proponents viz., that such schemes make markets more closely approximate the nearly perfectly competitive "auction" markets, such as exist in commodity or stock exchanges. This parallel to auction markets will only be true where buyers have equal access to such information. One writer has in fact concluded that making information exclusively available to sellers may only "... push an imperfectly competitive market toward the cartel model and away from the competitive model. . ."76

It is arguable, however, that informing all buyers of price discounts may be anticompetitive in a certain sense. This could result because of pressure from buyers to make what would otherwise be isolated discounts generally applicable. This pressure for a generalized price cut to all buyers may in turn cause some sellers to refrain from giving any discounts. ${ }^{77}$

\section{(e) Time Lags Between Closing of Transactions and Reporting}

If the conveying of price information only serves the purpose of making sellers better informed of market conditions, it should not be necessary that such data be filed immediately. In general, ". . . the shorter the reporting lag, the more useful becomes the information as a means of disciplining individual buyers, and sellers. . ." 78 This is true whether disciplining is to be for enforcement of a price fixing conspiracy or of mere interdependent behaviour.

\section{(f) Interpretation of Data Filed}

Sometimes data filed in conjunction with reporting schemes is later interpreted by trade association officials, either at meetings or in circulars. Some interpretations are clearly objectionable. A classic example can be found in U.S. v. American Column \& Lumber. ${ }^{79}$ In

74. Kaysen \& Turner, supra n. 52 at 151 : Stocking, supra n. 16 at 546.

75. American Column \& Lumber Co. v. U.S. (1921) 257 U.S. 377; U.S. v. American Linseed Oil Col. (1923) 262 U.S. 371 at 389 - 390; Cf. Maple Flooring Manufacturers Assoc. v. U.S. (1928) 268 U.S. 563; Tag Manufacturers Institute v. F.T.C. (1949) 174 F. (2d) 452 , at 462.463 .

76. Stocking, supra n. 16 at 610, commenting on the Tag Manufacturers case, id., which the pricing data, while theoretically available to buyers, was not practically available.

77. See generally Heath, supra n. 58 at 482.

78. Kaysen \& Turner, supra n. 52 at 151 . They recommend a one-week period as the threshold of what should be required as suspicious. See also Heath, supra n. 58 at $480 \cdot 481$.

79. (1921) 257 U.S. 377. 


\section{that case the following statements were circularized:80}

There is no agreement to follow the practice of others, although members do naturally follow their most intelligent competitors if they know what these competitors have been actually doing. [Emphasis in original]

Generally, any suggestions or interpretations that prices are too low or production too high ought to be regarded as objectionable. In the United States the practice of interpreting data in such a manner is now avoided, largely out of fear of contravening the antitrust laws. ${ }^{81}$ In any event, intelligent businessmen ought to be able to discern, from the statistical data itself, whether conditions of oversupply exist. ${ }^{82}$

Not much needs to be said about gatherings of competitors at trade association meetings where the data collected is discussed. Long ago Adam Smith pointedly commented that "People of the same trade seldom meet together, even for merriment and diversion, but the conversation ends in a conspiracy against the public, or in some contrivance to raise prices". Scherer has described the potential role of the modern trade association meeting: ${ }^{83}$

... the trade association convention [is] held in a resort hotel, where members who have been cutting prices are alternatively browbeaten, plied with martinis, and cajoled until they pro mise to adopt a more 'gentlemanly' stance in the future.

Some of the above practices are clearly more objectionable than others, especially the identification of individual competitors and customers, and the interpretation of data. Nevertheless, the presence of any one, or any combination, of the above factors and terms, does not conclusively prove price fixing, particularly given the criminal burden and standard of proof.

Yet experience in both the United States and Canada does indicate that data dissemination schemes have been used to facilitate and cloak covert price fixing conspiracies. ${ }^{84}$ Further, because any benign purposes which some of the above terms supposedly effect can usually be implemented by means less restrictive of competition, arguments have been made that they should be prohibited per se. For example, Kaysen and Turner conclude that any of the following features should render an agreement illegal per se:85

1.) Agreements to abide by list prices.

2.) Reporting of offers.

3.) Identification of individual buyers and sellers.

4.) Refusing to make reports available to buyers.

5.) Opening competitors books to each other.

6.) Reporting transactions without a time lag.

80. Id. at 393 .

81. See Lamb \& Shield, Trade Association Law and Practice (1971) 50.

82. Lamb and Shield, supra n. 81 at 50.

83. Scherer, supra n. 58 at 159.

84. For a review and assessment of the leading American cases see Stocking, supra $n$. 16 In Canada, price fixing conspiracies condemned in Howard Smith Paper Mills v. The Queen [1957] S.C.R. 403 and $R$. v. St. Lawrence Corporation (1969) 5 D.L.R. (3d) 263 (Ont. C.A.) had elements of overt information exchange agreements. In the latter case what was involved was the exchange and distribution of a cost manual. For a summary of RTPC reports involving information agreements see O.E.C.D. "Report by the Committee of Experts on Restrictive Business Practices on information agreements", excerpted in (1968) 13 Antitrust Bull. 225 at 240-245.

85. Kaysen \& Turner, supre n. 52 at 150. 


\section{B. The Legality of Data Dissemination Agreements Under Section 32 of the Combines Investigation Act}

The question of concern here is the extent to which business entities may enter into agreements to exchange pricing and other information without running afoul of s. 32(1) of the CIA. Section 32(1), the conspiracy section, prohibits agreements or arrangements which unduly lessen competition.86 Section 32(2), however, excepts certain types of agreements from this basic prohibition. It reads:

Subject to ss. (3), in the prosecution under ss. (1), the court shall not convict the accused if the conspiracy, combination, agreement or arrangement relates only to one or more of the following: -

(a) The exchange of statistics

(b) The defining of product standards,

(c) The exchange of credit information,

(d) The definition of terminology used in a trade, industry or profession.

(e) Cooperation in research and development,

(f) The restriction of advertising or promotion, other than a discriminatory restriction directed against a member of the mass media,

(g) The sizes or shapes of containers in which the article is packaged,

(h) The adoption of the metric system of weights and measures, or

(i) Measures to protect the environment.

Of relevance here are sub-sections (a) and (d). Conceivably, agreements to exchange price lists, file off-list prices, average prices, etc. may fall within (a) as being an agreement relating only to the "exchange of statistics". In addition, agreements relating to cost accounting may fall within (d), as agreements relating only to "the definition of terminology used in a trade, industry or profession". If basic data dissemination agreements can be so interpreted then they may fall within a clear statutory exception.

However, this is complicated by s. $32(3)$ which restricts the applicability of the exception found in $\mathrm{s}$. 32(2). Section $32(3)$ reads:-

Sub-section (2) does not apply if the conspiracy, combination, agreement or arrangement has lessened or is likely to lessen competition unduly in respect of one of the following:-

(a) Prices,

(b) Quantity or quality of production.

(c) Markets or customers, or

(d) Channels or methods of distribution,

or, if the conspiracy, combination, agreement or arrangement has restricted or is likely to restrict any person from entering into or expanding a business in a trade, industry or pro. fession.

The effect of ss. 32(2) and (3) when read together is most peculiar. It is that the nine types of agreements listed in s. 32(2) are excepted

86. S. 32(1) reads in full;

32.(1) Every one who conspires, combines, agrees or arranges with another person.

(a) to limit unduly the facilities for transporting, producing, manufacturing, supply. ing, storing or dealing in any product,

(b) to prevent, limit or lessen, unduly, the manufacture or production of a product, or to enhance unreasonably the price thereof,

(c) to prevent, or lessen, unduly, competition in the production, manufacture, purchase, barter, sale, storage, rental, transportation or supply of a product, or in the price of insurance upon persons or property, or

(d) to otherwise restrain or injure competition unduly,

is guilty of an indictable offence and is liable to imprisonment for five years or a fine of one million dollars or to both. 
from the basic prohibition in s. 32(1) only if they do not lessen competition unduly. However, if an agreement of the type listed in s. 32(2) does not restrain or limit competition unduly, it would not fall within s. 32(1) in the first place, "undueness" being an integral element of the offence. In short, it seems that ss. $32(2)$ and (3) only except agreements which would never have contravened s. 32(1), even apart from the exception in s. 32(2). The exceptions set forth in s. 32(2) appear to be superfluous.

Whatever may have been the motivation for the wording of these provisions in this way, it does seem possible to draw one important inference from them: the legislative intent must have been that at least some agreements relating to "the exchange of statistics" and the "definition of terminology used in a trade, industry or profession" fall within the scope of s. 32(1); otherwise why would Parliament have taken such care to explicitly indicate, as s. 32(3) clearly does, that the agreements listed in $s .32(2)$ are not excepted if they unduly lessen or limit competition? On the assumption that DDA s are in fact "agreements to exchange statistics", s. $32(3)$, by so restricting the exception in s. 32(2), may have manifested a legislative intent that some data dissemination agreements simpliciter are illegal. (It would not, I think, be possible to argue that the only reason for the enactment of $s .32(3)$ was to make clear that the agreements listed in s. 32(2) are not excepted where they in fact are but an element of a more covert price fixing conspiracy. Such agreements would not be excepted by s. 32(2), not because of the qualification in s. 32(3), but because s. 32(2) excepts agreements which relate ". . only to one or more of the following. ..".)

In $R$. v. Anthes Business Forms $L t d .{ }^{87}$ the legality of a DDA was before a Canadian court for the first time. In this case competitors in the business forms industry openly entered into a formal and rather elaborate DDA. The mechanism for implementation of this agreement was a trade association, "The Institute of Continuous Forms Manufacturers". The relevant terms of this agreement were:

1. Members were required to file with the secretary of the Institute their current price lists, specification of products, and terms of sale. Any changes in these standard prices or terms were also to be filed. The data thus filed was available to all other members of the Institute.

2. The agreement clearly stated that members were free to depart from the standard prices and terms. However, members so departing were required to file such departures with the secretary. Such departures were known as "special filings". The original agreement stated that such information was to be filed before a sale was concluded; the agreement was later amended to make it clear that such "special filings" were intended to apply after the sale was concluded. The trial Judge made a finding of fact that, "... it was never the intention of any of the parties to such agreement that the same should apply to anything but closed transactions. .."88

87. (1974) 16 Can. Pat. R. (2d) 216.

88. Id. at 239. 
3. Such "special filings" were to be effective for three months from date of recording. Unlike the filing of current price lists, such departures were not circulated among the members. However, any member could request information in respect of "special filings" of other members by giving specific information as to a customer's name and order on which he was seeking information. Apparently these requests were most often made by members who had bid on a tender and lost as well as by members who had lost repeat order business. Such requests were known as "special requests".

4. Members monthly reported their sales volume. These figures were then aggregated and data was returned to the members showing their market share for that month. As well, the secretary computed "for eastern members only" data on absolute amounts of orders at full list, and at a discount, as well as dollar amounts and appropriate percentages.

5. The secretary was entitled to make a special examination or audit at any time and was required to report to all members any breaches of the agreement.

6. There was also a practice, not found in the formal agreement, under which a member, believing an off-list sale has not been registered, could ask for an investigation to be undertaken by the secretary. It was normal to specify the suspected offending member. ${ }^{89}$

Given the existence of an agreement of this type, the obvious question of law that arises is whether such an agreement is itself illegal, or at least capable of being found illegal, without proof of any collateral or supplementary agreement to fix or stabilize prices. This question was undoubtedly recognized by the trial Judge; unfortunately it was phrased in an ambiguous and unsatisfactory manner.

Grant J. delineated three traditional categories of cases under s. 32:90

(i) actual price fixing schemes

(ii) market allocation schemes

(iii) output restriction schemes

He recognized that the case at hand did not "... fit into any of the above categories. .."91 He then phrased the question as follows: ${ }^{92}$

It should first be determined if those features of the Institute agreement, ex. 4, which require the exchange of each member's price list, the procedure described as special filings, enquiry by interested members and the system of investigation provided thereby, constitute sufficient evidence of a price maintenance scheme among the signatories thereto as to render the agreement illegal per se. [My emphasis]

This statement is ambiguous. In using the phrase "evidence of a price maintenance scheme", Grant J. could be referring to any one of three different types of agreements:

89. The full text of the agreement as amended can be found in the RTPC Report in the Matter of an Inquiry Relating to the Production. Manufacture, Sale or Supply of Printed Forms and Related Articles, No. 50 at 59 - 70. See pp. 37 - 43 for the practice in respect of investigations.

90. R. v. Anthes Business Forms Ltd. (1974) 16 Can. Pat. R. (2d) 216 at 242.

91. Id. at 242.

92. Id. at 243 . 
1. A traditional price fixing conspiracy. If this is what he meant then the DDA would be relevant only insofar as it constituted evidence of an actual price fixing conspiracy. At first glance, this seems to be what he meant. However, such an interpretation would be inconsistent with his initial statement that the case did not fit into any of the traditional s. 32 categories.

2. A DDA in which the parties do not actually agree on prices or any range of prices but which does have the effect of stabilizing prices.

3. A DDA in which the parties do not agree on prices or any range of prices, but through which the parties intend to bring about noncompetitive pricing behaviour, not through direct agreement on prices, but through facilitating interdependent pricing behaviour. Many, if not most, data dissemination agreements would fall within this category. (This is really a variation of the second type of agreement).

The ambiguity in the judgment is heightened by other remarks made by the trial Judge: 93

It is possible that knowledge of the price paid by purchaser (sic) of business forms on the last occasion might have the effect of persuading the competitor to shave the amount of the discount he was willing to offer on the following order to a lesser degree than he would have if he were ignorant of such fact. It could have the effect of keeping all quotes within a narrower ambit, but there is no evidence of such result in the present case. [My emphasis]

The above statement certainly is accurate in depicting a possible stabilizing effect of data dissemination agreements. It also seems to imply that Grant J. was inquiring into the effects of the agreement in issue and not the narrow evidentiary question of whether or not there was an underlying, more covert, conspiracy. That is, if it had been found that the effect was to narrow the range of bids or quotations, then perhaps the agreement might have been found illegal. Yet such a price stabilization would have been the result of each competitor independently using the data field, and not of any direct collusion on price.

The actual decision in the case is consistent both with an interpretation that the court was inquiring into whether or not there was price fixing and with one that the court was really inquiring into the anticompetitive effects of a DDA. The court ultimately found that: 94

...participation in such an arrangement on the facts established and as found by me in this case do not per se constitute an infraction of the section, and that membership alone in the Institute is not sufficient basis on which to base a conviction.

To succeed the Crown is obliged to prove the existence of an agreement or understanding. outside of or collateral to, the Institute agreement, the purpose of which was to prevent or lessen the competition referred to in the indictment. [My emphasis]

This does not indicate that such agreements simpliciter can never be illegal; rather, it is qualified by findings of fact. Those findings were a) significant deviations by competitors from filed list prices and b) the fact that the agreement in question gave rise to "... other valid benefits to members of the Institute, which may have been the reason for its conception, which are equally consistent with the innocence of the accused." 95 (Presumably these valid benefits were the enabling of 
competitors "... to provide a better service and more competitive prices. ..")96

Consider the possibilities if the court had found that prices quoted had either tended to be uniform or that there was little or no discounting. Quite conceivably, according to the reasoning of the court, the agreement might have been found illegal per se. However, such a finding of illegality could be premised on a finding that the evidence (i.e., the formal agreement plus price uniformity) was inconsistent with any rational conclusion other than price fixing. This would represent nothing new in terms of the law. On the other hand, a finding of illegality would also be quite consistent with a conclusion of law that DDA's, depending on the effects of such agreements in a particular case, can be illegal without proof of price fixing and that the effects in this (hypothetical) case are such as to render this particular agreement illegal.

In coming to the conclusion that this particular data dissemination agreement was not illegal per se the learned trial judge considered at length a recent American Supreme Court decision involving a DDA, U.S. v. Container Corporation of America. ${ }^{97}$ Because the court's determination on the issue of per se illegality seems based, at least in part, on the court's interpretation of the principles set forth in that case, it is instructive to examine this American decision.

In the Container Corporation case the defendants were producers of corrugated containers in the South Eastern United States. They would request information from each other about the most recent prices charged. The defendants usually acceded to such requests in the expectation that they too would receive such information when they requested it. From these facts the court found a combination or conspiracy to exchange information. ${ }^{98} \mathrm{Mr}$. Justice Douglas, speaking for the majority of the court, found that the effect of "... this reciprocal exchange of prices was to stabilize prices though at a downward level." 99 While finding that some price competition still existed he noted that this was "... not fatal to the Government's case. .." and, "...The limitation or reduction of price competition brings the case within the ban, for .... interference with the setting of price by free market forces is unlawful per se."100 Some commentators have postulated that the court was setting forth a per se prohibition on price exchange agreements, in particular market structures (oligopolistic, fungible product, competition by price, inelastic demand), ${ }^{101}$ whereas others have found the majority judgment sufficiently ambiguous as to be consistent with a mere finding on the facts, i.e. in this case there was evidence of price stabilization resulting from the agreement to exchange pricing data so as to render this particular agreement illegal.102

96. Id. at 255.

97. (1968) 393 U.S. 333.

98. The ease with which the Court found an agreement from these facts is commented on in a note at (1969) 83 Harv. L. Rev. 227.

99. U.S. v. Container Corporation (1969) 393 U.S. 333 at 336.

100. Id. at 337 .

101. Supra n. 98 at $233-234$.

102. See James M. Kefauver, "The legality of dissemination of market data by trade association: What does Container hold?" (1972) 57 Corn. L. Rev. 777. 
$\mathrm{Mr}$. Justice Fortas, concurring with the majority, did not interpret the majority as setting forth a per se ban on price exchange agreements, but as being based on a finding of fact that there was sufficient evidence of an unlawful effect on prices as opposed to a mere theoretical probability. Mr. Justice Marshall, with whom Mr. Justice Harlan and Mr. Justice Stewart joined in dissenting, argued:103

I do not believe that the agreement in the present case is so devoid of potential benefits or so inherently harmful that we are justified in condemning it without proof that it was entered in to for the purpose of restraining price competition or that it actually had that effect.

He ultimately disagreed with Fortas $J$. and found that as a question of evidence the Government had not proved its case.

It is important to stress that none of the judgments in the Container Corporation case stated that actual price fixing must be proved. The difference between the judgments is based on whether a) in point of law price exchange agreements in certain market structures are illegal per se, and b) on the question of fact of whether the Government had adduced sufficient evidence of harmful anti-competitive effects resulting from the agreement.

After reviewing the Container Corporation case, Grant J. aparently preferred the judgment of Fortas $\mathrm{J}$. and interpreted that case as holding that ". . . theoretical probability be buttressed by evidence as to the actual intent and effect of the agreement."104 In interpreting the case as requiring proof of intent and effect, the learned trial Judge was in error. Neither Fortas J. nor Marshall J. required proof of both intent and effect.

While not clearly stating that he was following Container Corporation (as he interpreted it), Grant J. did initially state that he was considering it because it would be "useful to an understanding of the implications of the agreement in the present case."105

Immediately following his interpretation of the Container Corporation case and one other American decision 106 he stated:107

"While an agreement in the form of ex. 4, may be an instrument or medium whereby manufacturers of the same product fix prices or a narrow area therefor among themselves and thereby hinder or lessen competition in the sale thereof, I am not prepared to hold every such agreement is arranged for that purpose or is used to bring about that result." [My emphasis]

The fact that this statement is made immediately following his consideration of the Container Corporation case and particularly his use of the emphasized words does tend to lend some weight to the view that Grant J. was implying that at least in some cases price exchange schemes may be illegal because of the effects which such schemes may have on prices and not merely because they manifest a more covert conspiracy.

103. U.S. v. Container Corporation (1969) 393 U.S. 333 at 341.

104. R. v. Anthes Business Forms Ltd. (1974) 16 Can. Pat. R. (2d) 216 at 249.

105. Id. at 244.

106. Id. at 244 - 247. Grant J. referred to Tag Manufacturers Institute v. F.T.C. (1949) $174 \mathrm{~F}$. (2d) 452 , a decision in which the legality of a DDA was upheld, but found the Anthes DDA distinguishable on the grounds that the data was not available to the public and because it provided data on individual transactions.

107. Id. at 249. 
Ultimately, after finding that the facts were not such as to render this particular DDA illegal per se, the trial court also found that there was not sufficient evidence to support a finding of an agreement collateral to the Institute agreement.

The Court of Appeal decision does not shed any further light on how DDA s ought to be legally treated. The Court of Appeal apparently initially believed that counsel for the Crown was relying on a per se doctrine similar to what it thought to be set forth in the Container Corporation case. ${ }^{108}$ However, the Court was assured that the Crown was not relying on such a doctrine but rather was maintaining that the trial Judge erred in that: 109

... the crime is in the agreement; it is not necessary for the Crown to show that the con spiracy was successful or that it was even capable of being put into effect. . . In this case, however, there were results which showed what the Institute was doing.

The court treated this as a question of fact and not an error of law and reluctantly refused to overrule the trial judge on this point since there was some evidence to support the inferences drawn by him.110 It is unfortunate that the court did not take the opportunity to comment on precisely what the Crown did have to prove. Either the Crown had to prove an agreement or arrangement to fix prices or else the Crown had to prove an agreement or arrangement to exchange pricing information which had deleterious effect on price competition, or which was intended to have such deleterious effect. While the facts, as found by the trial Judge, are capable of being interpreted as being inconsistent with either type of agreement,"11' and while the Court of Appeal may have been correct in not overruling what was perceived by the Court of Appeal as being a question of fact, or at least of inferences to be drawn from given facts, the failure of the higher court to accurately state what the law is with respect to DDA s, when taken together with the basic ambiguity of the trial court judgment, can only add to the uncertainty which business entities and their legal advisors must face when considering whether to implement a DDA.

108. R. v. Anthes Business Forms Ltd. (1975) 20 Can. Pat. R. (2d) 1 at 17 (Ont. C.A.).

109. Id. at 18.

110. Houlden J.A. concluded, "Despite the result I arrived at, I wish to make it clear that I do not necessarily agree with the inferences drawn by the trial Judge. If, instead of being limited to an appeal on questions of law, there had been a full-scale appeal in this case, the result of this appeal would probably have been different." Id. at 39 .

111. The evidence most favourable to the accused was data indicating continuing discounting through the years the Institute agreement was in force. From this Grant J. concluded that, ". . there was a continuing active effective effort on the part of the accused corporations to retain the customers they were serving and to acquire the business of competitors by offering their merchandise at such discount below the list price as they thought sufficient to acquire such business." (1974) 16 Can. Pat. R. (2d) 216 at $252-253$. The RTPC, supra n. 89 at 57 , apparently interpreted this as indicating a price-fixing agreement which was simply unsuccessful: "The detrimental nature of the arrangements from the viewpoint of the public interest is obvious regardless of whether they succeeded as well as some participants had hoped when they joined the Institute." While it is true that there was evidence of discounting through the period of the agreement, there is also evidence that both the rate and quantum of discounts was reduced as a result of the agreement. See particularly the RTPC Report at 52 - 57. A reduction, though not necessarily an elimination of discounting would be an expected result of a DDA where the object is "only" to facilitate oligopolistic interdependence and not actually fix prices. If this was the object of the Anthes DDA it apparently was successful in bringing it about. See Heath, supra n. 60 and accompanying text. 
In summary, the legal status of DDA $s$ under the CIA is unclear. A theoretical argument can be made that they are capable of being being caught by $\mathbf{s}$. 32. The legislation, after all, is not on its face restricted to actual price fixing or market allocation conspiracies. Rather it refers only to agreements to prevent or lessen, unduly, competition. Many DDA s as we have seen, do in fact lessen competition, and many certainly have the facilitation of interdependent behavior as a direct object. There is, as well, the argument that it would not have been necessary to enact s. 32(3) unless Parliament intended to make clear that some statistical exchanges are illegal because of their probable anti-competitive consequences. The case law, consisting largely of the trial and appeal judgments in the Anthes decision, raises the possibility that DDA s simpliciter may under certain circumstances be illegal, but fails to authoritatively put forward any but the vaguest criteria of legality.

\section{Evaluation of the Law and Proposals for Reform}

The present state of the law as it relates to DDA $s$ is unsatisfactory. First, as is the case with OPA s, the law is very uncertain and without any true precedent. However, in this area the law is more uncertain than in most, to the point where the question whether DDA's ever fall within the ambit of $s .32$ (other than as part of a covert price-fixing scheme) cannot be answered. It would be unwise perhaps for business entities, trade associations and their legal advisors to interpret the Anthes decision as meaning that all DDA s are excepted from s. 32. The case never authoritatively stated any proposition of the sort. There is sufficient ambiguity in the judgment for the Crown to argue that DDA s simpliciter are capable of falling within the ambit of s. 32 , and that whether any particular such agreement is illegal depends on the effects or intended effects of such agreements. Such a view of the law would be similar to the opinion of Fortas J. in the Container Corporation case.112 If so, a DDA which, unlike that in the Anthes case, actually resulted in price uniformity where none existed before or in a substantial lessening of discounting, might be prohibited. The possibility that some DDA $s$ are legal and others are not should not be surprising. After all, the fact that not all price fixing agreements are illegal 113 does not imply a blanket immunity for price fixing.

Let us however assume, for the purposes of discussion, that Anthes does stand for the narrow proposition that DDA $s$ are excepted from the operation of $s$. 32, and that they are relevant only to the extent they evidence covert or "collateral" price fixing conspiracies. Even under this very narrow interpretation of Anthes, or assuming that whatever the theoretical legal arguments, DDA s simpliciter are de facto excepted (this is a probable result of the case), it might still be unwise for parties to enter into a DDA. This is so because, given the "stabilizing" effects on pricing and discounting which are normally caused by DDA $s$ and which are usually intended by the parties, it is

112. U.S. v. Container Corporation (1969) 393 U.S. 333.

113. Aetna Insurance Company v. The Queen [1978] 1 S.C.R. 731, (1977) 75 D.L.R. (3d) 332. 
not difficult to envisage a court inferring an actual price fixing conspiracy from the combination of the formal agreement and the resulting price uniformity, even where none in fact existed. Note that in the Anthes case Grant J., in the trial judgment, emphasized in acquitting the accused the substantial discounting from price lists which occurred in the period alleged in the indictment. Such substantial discounting could not be expected to be the natural result in all cases of DDA s.

Whatever the present legal status may be, it is desirable that they be controlled or regulated in some manner. To the extent that they can constitute but one element of a price fixing conspiracy, the present criminal prohibition in s. 32 is probably sufficient.

To the extent that DDA s should be regulated because of their tendencies to facilitate oligopolistic interdependence the basic criminal prohibition found in s. 32 is neither an efficient nor a just mode of regulation. There are two reasons for the inadequacy of $\mathrm{s}$. 32 in this regard. First, despite the theoretical arguments that can be made to the contrary, I must concede that, given the present judicial approach to s. 32 cases, it is difficult to conceive of a Canadian court striking down a DDA solely on the grounds that the natural tendency is to facilitate conscious parallelism and price leadership or that it actually had that effect. If this assessment is accurate, then the present criminal prohibition of illegal conspiracies found in s. 32 is obviously ineffective as a means of control.

Secondly, even if DDA s do fall within s. 32, (or if the CIA were amended to make it clear that at least some DDA $s$ were prohibited) it is not at all clear that criminal prohibition is a just means of regulating this particular type of trade practice. Criminal prohibition is a rather blunt instrument best reserved for those practices which are both readily definable and almost always harmful to the public interest. DDA $s$ are, to be sure, sometimes harmful but in other market structures the effects on competition arising from the very same agreements may be neutral. Likewise, not all facets of DDA's are harmful; some terms may even be beneficial to competition. It would, I think, be very difficult to draft a prohibition which would define precisely what was sought to be prohibited and in what circumstances. Even if some sort of prohibition were drafted it is likely that it would also have the effect of deterring DDA $s$ whose impact on competition is neutral or even benign.114

A comparison with the treatment of DDA $s$ in the United States under s. 1 of the Sherman Act 115 is not helpful. Depending on whether one accepts the judgment of Justice Douglas or Justice Fortas in Container Corporation"16 the American position is that DDA s (at least insofar as they relate to exchange of prices) are either prohibited per se in oligopolistic market structures, or, will violate section 1 if actual anti-competitive effects (price stabilization) can be proved on the facts. While the Sherman Act is essentially criminal legislation, 117

114. But see the proposals of Kaysen \& Turner, supra n. 85 and accompanying text.

115. 15 U.S.C. $=1$.

116. (1969) 393 U.S. 333. See also, supra n. 99 - 103 and accompanying text.

117. S. 1 specifically provides that any violation of the section is a misdemeanor punishable by a fine of up to $\$ 50,000$ and/or imprisonment not exceeding one year. 
this is somewhat misleading. A great many Sherman Act proceedings are not in fact criminal prosecutions, but are civil "equity" proceedings, under which the Government is seeking only an injunction restraining the parties from engaging in that conduct in the future.118 Proceeding by way of such a civil action has obvious advantages:

1. Particularly in the area of anti-trust law it may be desirable for the Government to seek a prohibition of certain types of conduct, but in circumstances where a criminal prosecution with all its implications would be clearly inappropriate. This would be so where the conduct sought to be enjoined under the admittedly vague language of the Sherman Act had not been previously known to be a violation of the Act, or where the conduct complained of cannot be characterized as sufficiently reprehensible such as to justify criminal proceedings."119 In general, ". . . criminal prosecution. . . and imprisonment in particular, has been confined to instances of outrageous conduct of undoubted illegality".120

2. The eivil anti-trust action has enabled the American courts to "... develop a common law of anti-trust ..."121 under the Sherman Act. It seems clear that the American judiciary have been willing to develop the law in this manner, largely because they have been able to deal with new forms of anti-competitive behavior in the context of a civil action, where finding in favour of the Government has not entailed the levying of criminal penalties and the stigmatization of the defendants as criminals. There is no doubt that many leading American anti-trust decisions would have been differently decided had the proceedings been criminal instead of civil.122

It is noteworthy that all leading DDA decisions in the United States have been civil proceedings. In Canada, the only procedure truly analagous to the U.S. Justice Department's civil anti-trust action is found in s. 30(2) of the CIA wherein it is possible for the prosecuting authorities to seek a court order prohibiting "... the commission of the offence or the doing or continuation of any act or thing by that person or any other person constituting or directed toward the commission of such an offence. . ."123 Like the civil anti-trust action under the Sherman Act, the order under s. 30(2) prohibits the offence or acts constituting the offence without entailing criminal sanctions and the

118. These proceedings in "equity" are specifically provided for in s. 4 of the Sherman Act.

119. For an account of the enforcement procedures under American antitrust legislation see generally. Areeda, Antitrust Analysis, (2nd ed. 1974) 49 et. seg.; Neale. The Antitrust Laws of the U.S.A., (2nd ed. 1970) 2 - 5 .

120. Areeda, supra n. 119 at 50.

121. Id. at 53 .

122. Id.

123. Under s. 30(1) an order or prohibition is also available where a person has actually been convicted of an offence. There is also a provision in $\mathbf{s} .29 .1$ by which the Crown can seek an injunction. However, it is clear that this is only an interim remedy; under s. 29.1(6), the Crown is obligated "as expeditiously as possible to institute and conclude any prosecution or proceedings arising out of the actions on the basis of which the injunction was issued." It is only under s. 30(2) that the prosecuting authorities can "prohibit" the continuation of the offence without seeking a criminal conviction. 
stigma of a criminal conviction. For some reason, however, it has not been utilized with anywhere near the same effect as the Sherman Act "equity" or injunctive proceedings. (This is unfortunate; there are many areas of Canadian combines law which are ideally suited to this sort of proceeding.124)

The new category of "reviewable trade practices" under the Combines Investigation Act does bear certain similarities to the American civil action. Such practices are generally legal until prohibited and an order of the RTPC prohibiting such practice involves no criminal penalties. ${ }^{125}$ It differs from the American civil anti-trust action under the Sherman Act in two respects. First, and obviously, it is a Commission and not a court which makes the order prohibiting the conduct in question. Secondly and more importantly it does not have the effect of developing new law. An order issued by the RTPC does not prohibit the conduct in general; it only prohibits the conduct of those named in the order. Those not so named can presumably engage in the conduct until they are enjoined from doing so by another order from RTPC. The American civil action, on the other hand, while also specifically enjoining only those named in the court order, does in addition interpret what constitutes a substantive violation of the Sherman Act. It thus has the effect of making new law of general application. (It was in this manner that the American "common law" of anti-trust developed.) The American civil anti-trust decision is thus "informational" in a way that a RTPC reviewable trade practice decision can never be. It informs both lower courts and potential defendants of the parameters of acceptable behavior under the anti-trust laws.

124. An illustration of the practical value of seeking only an order of prohibition can be found in $R$. v. Canadian Safeway Ltd. (1973) 14 C.C.C. (2d) 14 (Alta. S.C. T.D.) in which the Court granted an Order of prohibition under s. 30(2). The case had connota. tions of "plea bargaining". The Crown dropped the prosecution of an alleged offence of monopoly and the accused consented to the order of prohibition, supposedly in order to avoid costly litigation. It is, in my opinion, doubtful whether the Crown would have been successful under Canada's rather lax monopoly laws, had it continued the prosecution. For the use, and a statistical summary, of prohibition orders under the CIA see Stanbury. "Penalties and remedies under the Combines Investigation Act" (1976) 14 Osgoode L.J. 571 at 577 - 578. Prof. Stanbury notes that in ". . over thirty percent of the cases (excluding misleading advertising) started and completed between 1960 and 1975 a prohibition order was the only remedy obtained. In such cases the prohibition order operates somewhat like a consent decree in the United States." Apparently the seeking of a prohibition order only, has been used where the Crown's case is weak and not where it would be useful in having borderline cases decided without resort to criminal sanctions.

125. The present reviewable trade practices are found in Part IV.1 ss. $31.2-31.7$ of the CIA. They include refusal to deal, consignment selling, exclusive dealing, market restrictions, tied selling, heeding foreign judgments or orders, heeding foreign laws or directions and refusals to supply by foreign suppliers. An Act to amend the Combines Investigation Act and to amend the Bank Act and other Acts in relation thereof or in consequence thereof, 3nd Sess., Bill C-13, 30th Parl., 1977 Bill C-13 (19 off.) would add to this list the highly contentious categories of mergers, monopolization, joint monopolization and price differentiation, as well as abuse of intellectual property and interlocking directorates. In addition, the Competition Board would be given the power to approve specialization agreements. Strictly speaking, specialization agreements would not be a receivable trade practice, which is a practice which is legal until reviewed and prohibited by the Board. Specialization agreements, would be generally illegal (under s. 32) until reviewed and allowed by the Board. 
It is far too late to hope that difficult and uncertain areas of combines law in Canada will be adquately disposed of by Canadian courts in the same manner as by American Courts under the American civil anti-trust action. Given this and the fact that the competitive effects of DDA s differ according to the market structure, the precise terms of the agreement, etc., making DDA $s$ a reviewable trade practice would seem to be the best solution to this thorny problem area of Canadian combines law. A commission, with the necessary expertise to appreciate and assess the sometimes elusive anti-competitive effects of DDA s, would be able to prohibit absolutely blatantly harmful DDA s, or perhaps prohibit only those aspects of DDA $s$ which are harmful.126

At present the decision confronting a Canadian court in a criminal prosecution of parties to a DDA under $\mathrm{s} .32$ is either to hold that the accused have committed a criminal offence by entering into a DDA and impose appropriate penalties or to acquit the accused. The injustice in convicting the accused of a criminal offence, based on conduct for which there have been no true judicial precedents to guide the accused, and which is not blatantly reprehensible is obvious. It is not too difficult to surmise the likely decision in such a case.

Yet there are certain aspects of at least some DDA $s$ which should be prohibited. In the Anthes case, for example, whether or not there was an actual price fixing conspiracy, certain features of the DDA in question were clearly objectionable. ${ }^{127}$ It would appear that from the point of view of public policy DDA s such as that in Anthes are far better dealt with by a Commission which can review them on a case by case basis. Certainly both economic theory and long American experience with such agreements indicate that there are sufficient anti-competitive consequences associated with them, such that some form of regulation is desirable. In the Canadian context, it would seem that the best public policy option is to make DDA $s$ a reviewable trade practice.

\section{SUMMARY}

Business entities should probably be advised not to enter into OPA s or DDA s. Most OPA s are probably illegal under s. 32(1) of the CIA; while most, if not all, DDA s simpliciter are probably not prohibited by the CIA, there is an element of uncertainty in the law which ought to make any lawyer think twice before advising a course

126. Stanbury \& Reschenthaler, supra n. 6, also propose that the exchange of price information, among other practices, should be reviewable as facilitative of conscious parallelism.

127. These features were: -

1) The reporting and identification of individual sellers and buyers in transactions other than at published prices.

2) Discretionary audits and publication of any breaches of the DDA.

3) The immediate reporting of departures from standard prices.

See generally supra n. 65 - 85 and accompanying text. 
of action which could constitute a criminal offence. Even if it is assumed that DDA s simplicitor are legal, there is always the possibility, arising from the nature of the evidence and the motivation of the parties, of being prosecuted and convicted, albeit wrongfully, for actual price fixing.

In terms of competition policy OPA $s$ are almost always harmful with no redeeming features whatsoever. They should thus be prohibited per se. The competitive effects of DDA s, on the other hand, are elusive and variable. A per se prohibition would thus seem to be inappropriate. However, because they often enough do have anticompetitive effects, some sort of regulation is desirable. The most effective manner of regulating $\mathrm{DDA}^{\mathrm{s}} \mathrm{s}$ in Canada would be making them a reviewable trade practice. 